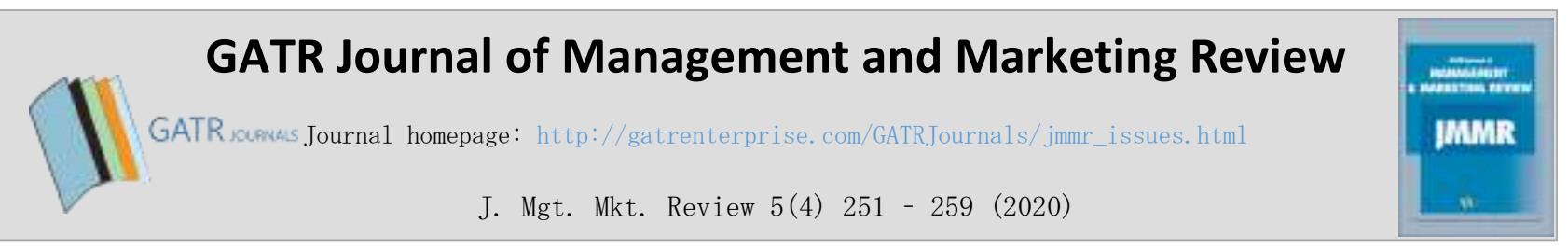

\title{
Influence of Consumer Buying Orientation and Pro-environmental Values on their Willingness to Patronise Green Hotels
}

\author{
Christina Appiah-Nimo ${ }^{1 *}$, Gloria K.Q. Agyapong ${ }^{2}$, Daniel Ofori ${ }^{3}$ \\ ${ }^{1}$ Department of Management and Marketing Faculty of Management and Economics Tomas Bata University in Zlin, Czechia \\ ${ }^{2,3}$ Department of Marketing and Supply Chain Management School of Business University of Cape Coast, Ghana
}

\begin{abstract}
Objective - Based on the theory of planned behaviour, this study empirically investigated and significantly validated the relationship among hedonistic buying orientation, utilitarian buying orientation, pro-environmental orientation. and willingness to patronise green hotels.

Methodology/Technique - This quantitative study used the survey technique in data collection among hotel customers. 208 online surveys were gathered for data analysis. Sem-pls was used to analyse the hypothesised objectives.

Findings - The findings indicated that pro-environmental values, hedonistic buying orientation and utilitarian buying orientation all have a positive and significant relationship with their willingness to patronise green hotels.

Novelty - The value of this study lies in the novel use of consumer buying orientation as a predictive factor of consumers' willingness to patronise green hotels, and to the best of the authors knowledge, it is among the first to empirically test such relationship. This study is useful to key stakeholders in the hospitality sector and managers of hotels to understand consumers pro-environmental patronage.

Type of Paper: Empirical.

JEL Classification: M31, M39.

Keywords: Consumer Buying Orientation; Willingness to Patronise Green Hotel; Pro-Environmental Value.

Reference to this paper should be made as follows: Nimo, C.A, Agyapong, G.K.Q; Ofori, D. (2020). Influence of Consumer Buying Orientation and Pro-environmental Values on their Willingness to Patronise Green Hotels, J. Mgt. Mkt. Review, 5(4) 251 - 259. https://doi.org/10.35609/jmmr.2020.5.4(7)
\end{abstract}

\section{Introduction}

UN sustainable development goals have triggered production and consumption patterns aimed at achieving a better and more sustainable future for all by 2030. Sustainable value chain has become a business approach to mitigate the tragedy of the commons. Initiatives that promote socially and environmentally responsible behavior while pursuing business value is being leveraged across all economic sectors. The global health crises (COVID-19), coupled with consumers' growing interest in the sustainable environment has also fueled the desire for more eco-friendly products by the hospitality sector.

\footnotetext{
* Paper Info: Revised: October 22, 2020

Accepted: December 31, 2020

* Corresponding author: Christina Appiah-Nimo

E-mail: appiah_nimo@utb.cz

Affiliation: Department of Management and Marketing Faculty of Management and Economics Tomas Bata University in Zlin, Czechia.
} 
Evidently, the hospitality sector has not been left out of this challenge as the tourism industry has been the worst hit by this pandemic. Indeed, the growth of the tourism industry is propelled by the movement of people and the subsequent need created for the hospitality sector. For over two decades now, consumers have been aware and conscious about green and ecologically friendly products pushing companies towards this movement. However, every consumer goes through a cognitive decision-making process to finally make a choice for a product - and there is a high probability of the decision to inform the sustainable consumption pattern of the consumer and also the magnitude of the effect the decision will have on the environment. This implies that every consumer purchase intention has implications regarding not only economics (Stone, 1954) but ethics and sustainability of the environment. And arguably, consumers' intention towards the patronage of hotels are affected by policies that regards the environment as a whole by these hotels (Han \& Yoon, 2015). The concept of sustainable consumer behavior explains how consumers attempt to satisfy their needs and preferences while considering its impacts on the environment now, and in the future. This growing link of environmentalism with purchasing and consumption patterns is shaping business strategy towards creating value for the consumer while considering its sustainability impacts. The hotel and accommodation sector of the tourism industry is one of the most waste generating sectors due to its operations. It can be argued from the perspective of the hotels that implementing sustainable initiatives may pay off or not, but what role does the consumers pro-environmental orientation play in the relationship between consumer's shopping orientation (cognitive decision-making process) and willingness to patronize green hotels. Undoubtedly, although some consumers may be environmentally inclined (Goh \& Balaji, 2016), they may have challenges translating these intentions into actions. And this green consumerism has expanded in well developed economies but is now gaining grounds in developing economies like Ghana (Mensah, 2011; Breisinger, Diao, Thurlow \& Hassan, 2011). Marketers evidently need to understand what the consumer's perspective is towards patronizing green products. Extant literature on the antecedents of green consumer behavior confirms reference groups, routine behavior and ethical values as contributing factors (Welsch \& Kühling, 2009). And according to Chatzidakis, Hibbert and Smith (2007), there exists several other factors that inform one's behaviour. Employing the theory of planned behavior, this study assessed the consumer's buying orientation and pro-environmental values as antecedents to their willingness to patronize green hotels. The rest of the paper is organized as follows: review of related literature, followed by the research method, the discussion and implication of results, and finally conclusions and recommendations are presented.

\section{Literature Review}

\subsection{Theory of Planned behavior}

Scientists and researchers alike have over the years investigated and tried to explain the complex nature of human behaviour. And concepts of social attitude and personality traits have been touted as important factors to predict and explain people's behaviour. The theory of planned behavior (TPB) has been used by several studies to predict and understand human behavior. The TPB is an extension of the theory of reasoned action (TRA) (Ajzen \& Fishbien, 1977), and both assume that intentions are an immediate predictor of our actions. The TPB posits that intentions to perform certain behaviors or acts in a certain way is influenced by an attitude towards the behavior, subjective norms, and perceived behavioral control; and these intentions, together with perceptions of control over behavior, influence the behavior to occur (Ajzen, 1991 p. 179). The TPB has been applied in different environments and context to understand and predict behaviors, specifically, in the context of green consumerism in the hospitality sector (Wang, et al., 2019; Paul, Modi \& Patel, 2016). According to Park and $\mathrm{Ha}$ (2012), green consumerism includes the use of environmentally friendly products, practicing of proper waste disposal or recycling methods. It is noteworthy that TPB allows for the exploration of the impact other contextual variables have on consumer's behavior (Kumar, Manrai \& Manrai, 2017). Based on the flexibility of the theory, this study included consumers buying orientation and proenvironmental values to measure their willingness to patronize green hotels. The concept of green hotel 
basically refers to a hotel or accommodation unit that practices eco-friendly policies to protect the environment.

\subsection{Model description and hypothesis development}

\subsubsection{Consumer Buying Orientation}

Researchers of consumer behaviour have over the years of investigations discovered that a lot of consumption activities gives the consumer both a hedonistic and utilitarian effect. According to Babin, Darden and Griffin (1994) consumers are significantly impacted by their hedonistic and utilitarian values (self-oriented) to arrive at a buying decision. Hedonistic values, on one hand, refer to the emotional benefits a consumer derives from shopping for particular products while utilitarian values are explained by the 'work' mentality of the shopping (Babin et al., 1994). Booking a hotel is much involving because it is an infrequent activity, hence consumers need to critically evaluate their preferences versus what is offered at a good price. People, therefore, spend a considerable amount of time and effort on finding the most appropriate hotel accommodation to suit their taste. However, there is an overload of choice as consumers are exposed to numerous lists of hotels to choose from. This is where the utilitarian values set in - viewing the process of searching for a hotel as work or a task and how successful the search was (Holbrook, 1986). Thus, it involves a consumer searching for information due to necessity and not as a recreation, nevertheless, when the search for hotels rouses the consumers' emotions due to the adventure and pleasurable experience of the search, hedonistic values are thus perceived (Babin, et al., 1994). And because people's values motivate and affect their interpretation of information available to them, which subsequently influences the performance of a particular behaviour by means of intentions, this study contends that these values act as motivation which actually influences the behavioural intention to book a green hotel. There is some extant literature which supports that contextual factors including personal values of consumers influence their intention to purchase green hotels (Perlaviciute \& Steg, 2015). The study, therefore, hypothesized that:

H1: There is a relationship between hedonistic buying orientation and consumers' willingness to patronise green hotels.

$\mathrm{H} 2:$ There is a relationship between utilitarian buying orientation and consumers' willingness to patronise green hotels.

\subsubsection{Pro-environmental Values}

The introduction of the New Environmental Paradigm (NEP) has seen a rise in interest for environmental issues and its importance by society (Catton \& Dunlap, 1978). According to Dunlap and Jones (2002), environmental orientation refers to the degree to which humans are aware of the impact of the world activities on the environment and willingly contribute efforts towards its solution. Hence, pro-environmental orientation explains the consumers' understanding on environmental challenges and their conscious effort to act in a way which reduces or eliminates such impact on the environment. This orientation actually enables consumers to focus on environmental/green practices while processing information on hotels they plan to patronise. Rahman and Reynolds (2016) contend that such consumers put in a lot of effort to reduce the consequences their consumption pattern may have on the environment. Arguably, pro-environmental consumers will be motivated to patronise green hotels based on their green orientation. And some studies have confirmed a relationship between consumers with pro-environmental orientation and their intention to patronise green products (Verma, Chandra \& Kumar, 2019). The study, therefore, hypothesized that:

$\mathrm{H} 3:$ There is a positive relationship between consumers pro-environmental orientation and their willingness to patronise green hotels. 


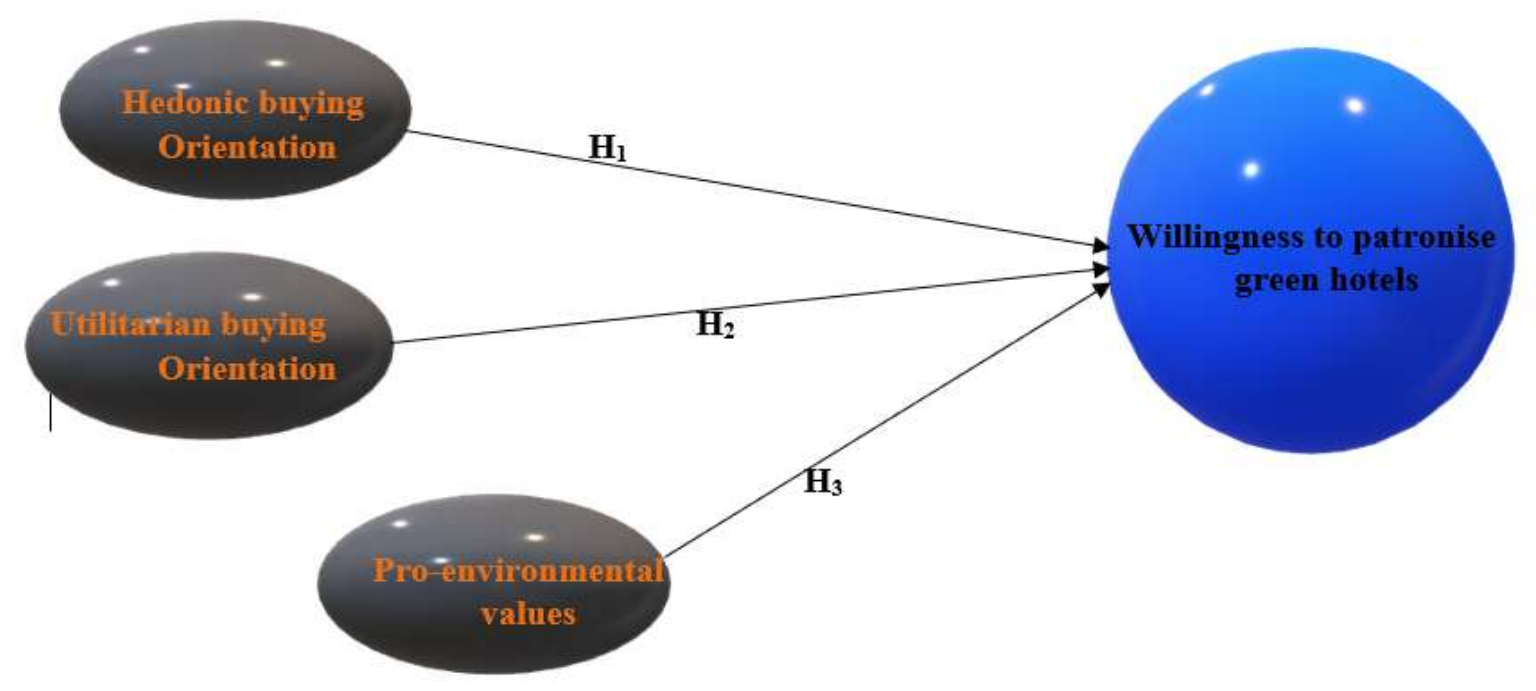

Figure 1: Conceptual framework with hypothesis

\section{Research Methods}

Quantitative approach was adopted in this study since relationships among pro-environmental values, hedonistic buying orientation, utilitarian buying orientation and willingness to purchase were assessed. The survey method was employed, and a questionnaire was used as a data collection instrument, administered via google forms (online survey). The target population included postgraduate students on distance and sandwich programmes because available statistics shows that most of them are working-class who may have patronised the services of hotels. 208 responses were obtained after one month with constant reminders. Nevertheless, the sample size met the minimum required sample size for the analytical approach employed. The partial least squares-structural equation modelling technique was deemed appropriate because our sampling procedure was non-probability. Again, primary data-based work hardly achieves the requirement of parametric analytical approach. Hence, it was vital to use an approach that is non-parametric for robustness and power.

\subsection{Instrument and Measurement}

The questionnaire was made up of items measuring hedonistic and utilitarian orientation, proenvironmental values and willingness to patronise green hotels. Hedonistic and utilitarian orientation was adapted from Babin, et al. (1994) conceptualisation of hedonistic and utilitarian shopping values. Proenvironmental orientation was based on the New Environmental Paradigm Scale (Dunlap et al., 2000). All items were scored on 5-point Likert-type scales. Finally, after conducting a reliability test, five indicators (B07, EV1, EV2, EV6, WTP 7) were not included in further analysis.

\section{Results}

\subsection{Measurement Model}

Composite reliability values of 0.7 and higher are recommended (Bagozzi \& Yi, 1988) and Table 1 depicts above 0.7 composite reliabilities. To check for convergent validity, Average Variance Extracted (AVE) was used which showed AVE values above 0.5 (Bagozzi \& Yi, 1988) hence convergent validity was achieved. 
Table 1: Validity and Reliability.

\begin{tabular}{cccc}
\hline & Loadings & Composite Reliability & AVE \\
\hline Pro-environmental Values & & & \\
EV3 & 0.695 & 0.907 & \\
EV4 & 0.840 & \\
EV5 & 0.726 & \\
EV7 & 0.769 & \\
EV8 & 0.860 & \\
EV9 & 0.821 & \\
Hedonistic Buying Orientation & & \\
BO1 & 0.692 & \\
BO2 & 0.709 & \\
BO4 & 0.766 & \\
BO5 & 0.786 & \\
BO6 & 0.753 & \\
BO9 & 0.807 & \\
BO3 & & \\
BO8 & 0.793 & \\
WTP & 0.879 & \\
WTP1 & & \\
WTP2 & 0.829 & \\
WTP3 & 0.804 & \\
WTP4 & 0.843 & \\
WTP5 & 0.849 & \\
WTP6 & 0.719 & \\
& 0.649 & & \\
& & & \\
Utilitarian & & \\
\end{tabular}

Fornell and Larcker (1981) proposed that the square root of the AVE values for every construct should be higher than the correlation values between that constructs and other constructs to achieve discriminant validity. Based on the results in Table 2, the Fornell-Larcker criterion was achieved and for that matter, discriminant validity was met.

Table 2: Fornell-Larcker Criterion.

\begin{tabular}{|c|c|c|c|c|}
\hline & $\begin{array}{c}\text { Pro-environmental } \\
\text { Values }\end{array}$ & $\begin{array}{c}\text { Hedonistic } \\
\text { Buying } \\
\text { Orientation }\end{array}$ & $\begin{array}{c}\text { Utilitarian Buying } \\
\text { Orientation }\end{array}$ & WTP \\
\hline Pro-environmental Values & $\mathbf{0 . 7 8 8}$ & & & \\
\hline Hedonistic Buying Orientation & 0.230 & $\mathbf{0 . 7 5 3}$ & & \\
\hline Utilitarian Buying Orientation & 0.305 & 0.543 & $\mathbf{0 . 8 3 7}$ & \\
\hline WTP & 0.602 & 0.389 & 0.393 & $\mathbf{0 . 7 8 6}$ \\
\hline
\end{tabular}

\subsection{Structural Model}

\subsubsection{Path coefficient}

Adopting a significant level of 5\%, the path coefficient values of the model were all significant and the tstatistics were also lower than 1.96, in Table 3. As shown in Table 3, the relationship between Proenvironmental Values and WTP was statistically significant $(\beta=0.517 ; \mathrm{t}=10.068 ; \mathrm{p}=0.000)$. The study also showed a statistically significant relationship between Hedonistic Buying Orientation and WTP $(\beta=$ 
$0.202 ; \mathrm{t}=3.373 ; \mathrm{p}=0.001)$. Finally, the relationship between Utilitarian Buying Orientation and WTP was also significant $(\beta=0.125 ; \mathrm{t}=1.988 ; \mathrm{p}=0.047)$.

Table 3: Statistics of Path Coefficients.

\begin{tabular}{|c|c|c|c|c|c|}
\hline Hypothesis & $\begin{array}{c}\text { Path Coefficients } \\
(\beta)\end{array}$ & $\begin{array}{c}\text { T Statistics } \\
(|\mathrm{O} / \mathrm{STDEV}|)\end{array}$ & P Values & Decision & $\begin{array}{c}\text { Effect } \\
\text { size (f2) }\end{array}$ \\
\hline $\begin{array}{c}\text { Hedonistic Buying Orientation -> } \\
\text { WTP }\end{array}$ & 0.202 & 3.373 & 0.001 & Supported & 0.051 \\
\hline $\begin{array}{c}\text { Utilitarian Buying Orientation -> } \\
\text { WTP }\end{array}$ & 0.125 & 1.988 & 0.047 & Supported & 0.019 \\
\hline $\begin{array}{c}\text { Pro-environmental Values -> } \\
\text { WTP }\end{array}$ & 0.517 & 10.068 & 0.000 & Supported & 0.430 \\
\hline
\end{tabular}

\subsubsection{Coefficient of determination}

The coefficient of determination value as shown in Table 4, that is the R2 value of 0.440 of WTP (the dependent variable) indicates that the three independent variables (hedonistic buying orientation, utilitarian buying orientation and consumers pro-environmental values) explain $44.0 \%$ of the variance in WTP.

Table 4: Coefficient of determination (R2) and assessment.

\begin{tabular}{|c|c|c|}
\hline & R2 & Assessment \\
\hline WTP & $\mathbf{0 . 4 4 0}$ & Moderate \\
\hline
\end{tabular}

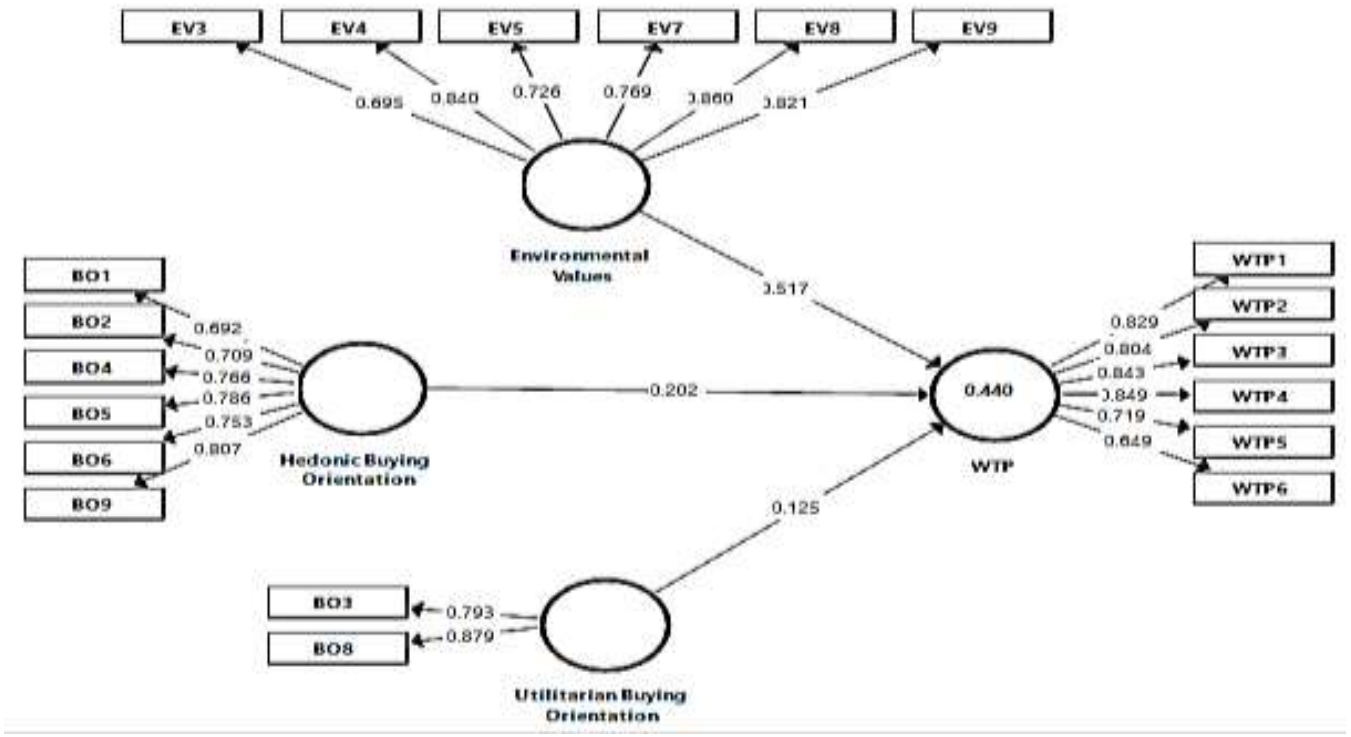

Figure 2: Structural Model

\section{Discussion and Implications}

This study sought to examine consumers thought process regarding their willingness to patronise green hotels. The first hypothesis was supported as hedonistic buying orientation had a significant and positive relationship with consumers' willingness to patronise green hotels. Thus, consumers who are concerned about their feelings (emotional worth) of enjoyment or fun while searching for hotels are willing to patronise 
green hotels. For example, a study by Dey and Srivastava (2017) found that indeed, a hedonistic buying value has a significant relationship to an impulse buying behaviour. Also, this finding is supported by Jaini et al. (2019) as they found hedonistic buying values to influence pro-environmental values which subsequently influences consumers green purchase behaviour. The second hypothesis was also supported as utilitarian buying orientation significantly and positively affected consumers' willingness to patronise green hotels. Consumers with a utilitarian orientation tend to be rational because they see the search for hotels as a work hence analyse every information in detail (Chang \& Cheng, 2015). This study is consistent with Liu, Yuen and Jiang (2019) who found that utilitarian consumers are more likely to patronise a sharing facility which has a clearly defined eco-friendly impact. Lastly, the pro-environmental orientation of consumers also had a highly significant and positive relationship with the willingness to patronise green hotels. This finding is consistent with a study by Wang (2020) who found that a consumer's environmental concern and knowledge influences their attitudes and intentions to patronise green products.

This study, to the best of the authors' knowledge is arguably among the first to empirically test and also validate significant antecedents (hedonistic buying orientation, utilitarian buying orientation and proenvironmental values) to consumers' willingness to patronise green hotels in a developing economy using SEM. Practically, hoteliers will find this study useful as appropriate marketing communication tools can be employed to increase awareness of their green practices and environmental policies to the consumer. Their promotions can also be targeted at consumers, augmenting the hedonistic and utilitarian experience of the hotels.

\section{Conclusion and Recommendations}

The study sought to investigate the decision-making process of consumers on their willingness to patronise green hotels. Specifically, it introduced consumer buying orientation (hedonistic and utilitarian) and the consumers' pro-environmental values as antecedents to their willingness to patronise green hotels. Adopting the theory of planned behaviour, it examined hedonistic and utilitarian buying behaviour and proenvironmental orientation as predicting the willingness to patronise green hotels. The findings revealed that all the exogenous variables had a positive and significant relationship with the endogenous variable.

It is recommended that stakeholders in the sector as well as hotel managers should communicate more through marketing campaigns on sustainable consumption patterns in order to increase awareness of the hotel's green practices to consumers - this is due to the results of the study which suggests that consumer's pro-environmental values influence their willingness to patronise green hotels. Meaning, activities that promotes green consumerism should be augmented and appropriate opportunities (loyalty programmes) should be created to encourage such habits among consumers. The study also highlights the importance of hedonistic and utilitarian buying orientation on willingness to patronise green hotels, hence hoteliers can identify and exploit these factors to their benefit.

\section{Acknowledgement}

The first author acknowledges the support by the Internal Grant Agency of FaME through TBU in Zlín No. IGA/FaME/2020/002; Project title: The impact of digital transformation on consumer behaviour and firm's sustainable performance.

\section{References}

Ajzen, I. (1991). The theory of planned behavior. Organizational behavior and human decision processes, 50(2), 179211. DOI:10.1016/0749-5978(91)90020-TAllen,P.

Ajzen, I. (2011). The theory of planned behaviour: Reactions and reflections. https://doi.org/10.1080/08870446.2011.613995 
Ajzen, I., \& Fishbein, M. (1977). Attitude-behavior relations: A theoretical analysis and review of empirical research. Psychological bulletin, 84(5), 888. DOI: https://doi.org/10.1037/0033-2909.84.5.888

Babin, B. J., Darden, W. R., \& Griffin, M. (1994). Work and/or fun: measuring hedonic and utilitarian shopping value. Journal of consumer research, 20(4), 644-656.DOI: https://doi.org/10.1086/209376

Bagozzi, R. P., \& Yi, Y. (1988). On the evaluation of structural equation models. Journal of the academy of marketing science, 16(1), 74-94. DOI: https://doi.org/10.1007/BF02723327

Breisinger, C., Diao, X., Thurlow, J., \& Hassan, R. M. A. (2011). Potential impacts of a green revolution in Africa-the case of Ghana. Journal of international development, 23(1), 82-102.DOI: $\quad$ https://doi.org/10.1002/jid.1641

Catton Jr, W. R., \& Dunlap, R. E. (1978). Environmental sociology: A new paradigm. The american sociologist, 41 49.DOI: http://www.jstor.org/stable/27702311

Chang, C. T., \& Cheng, Z. H. (2015). Tugging on heartstrings: shopping orientation, mindset, and consumer responses to cause-related marketing. Journal of Business Ethics, 127(2), 337-350. $\quad$ DOI: https://doi.org/10.1007/s10551014-2048-4

Chatzidakis, A., Hibbert, S., \& Smith, A. P. (2007). Why people don't take their concerns about fair trade to the supermarket: The role of neutralisation. Journal of business ethics, 74(1), 89-100. DOI: https://doi.org/10.1007/s10551006-9222-2

Dey, D. K., \& Srivastava, A. (2017). Impulse buying intentions of young consumers from a hedonic shopping perspective. Journal of Indian Business Research. https://doi.org/10.1108/JIBR-02-2017-0018

Dunlap, R. E., \& Jones, R. E. (2002). Environmental concern: Conceptual and measurement

issues. Handbook of environmental sociology, 3(6), 482-524.

Dunlap, R. E., Van Liere, K. D., Mertig, A. G., \& Jones, R. E. (2000). New trends in measuring environmental attitudes: measuring endorsement of the new ecological paradigm: a revised NEP scale. Journal of social issues, 56(3), 425-442.DOI: https://doi.org/10.1111/0022 4537.00176

Fornell, C., \& Larcker, D. F. (1981). Structural equation models with unobservable variables and measurement error: Algebra and statistics.DOI: https://doi.org/10.1177/002224378101800313

Goh, S. K., \& Balaji, M. S. (2016). Linking green skepticism to green purchase behavior. Journal of Cleaner Production, 131, 629-638. DOI: https://doi.org/10.1016/j.jclepro.2016.04.122

Han, H., \& Yoon, H. J. (2015). Hotel customers' environmentally responsible behavioral intention: Impact of key constructs on decision in green consumerism. International Journal of Hospitality Management, 45, 22-33.DOI: https://doi.org/10.1016/j.ijhm.2014.11.004

Holbrook, M. B. (1986). Aims, concepts, and methods for the representation of individual differences in esthetic responses to design features. Journal of consumer research, 13(3), 337-347.DOI: https://doi.org/10.1086/209073

Jaini, A., Quoquab, F., Mohammad, J., \& Hussin, N. (2019). I buy green products, do you?. International Journal of Pharmaceutical and Healthcare Marketing. https://doi.org/10.1108/IJPHM-02-2019-0017

Kumar, B., Manrai, A. K., \& Manrai, L. A. (2017). Purchasing behaviour for environmentally sustainable products: A conceptual framework and empirical study. Journal of Retailing and Consumer Services, 34, 1-9.DOI: https://doi.org/10.1016/j.jretconser.2016.09.004

Lin, H. F. (2007). Predicting consumer intentions to shop online: An empirical test of competing theories. Electronic Commerce Research and Applications, 6(4), 433-442. DOI: $\quad$ https://doi.org/10.1016/j.elerap.2007.02.002

Liu, Y. L., Yuen, T. W., \& Jiang, H. L. (2019). An experimental study of consumption orientations, environmental sustainability advertising and home-sharing adoption intentions. International Journal of Contemporary Hospitality Management.DOI: https://doi.org/10.1108/IJCHM-122018-0968

Mensah, I. (2014). Different shades of green: Environmental management in hotels in Accra. International Journal of Tourism Research, 16(5), 450-461. DOI: https://doi.org/10.1002/jtr.1939

Park, J., \& Ha, S. (2012). Understanding pro-environmental behavior: a comparison of sustainable consumers and apathetic consumers. International Journal of Retail \& Distribution Management, 40(5), 388-403. DOI: https://doi.org/10.1108/09590551211222367

Paul, J., Modi, A., \& Patel, J. (2016). Predicting green product consumption using theory of planned behavior and reasoned action. Journal of retailing and consumer services, 29, 123-134. DOI: https://doi.org/10.1016/j.jretconser.2015.11.006

Perlaviciute, G., \& Steg, L. (2015). The influence of values on evaluations of energy alternatives. Renewable energy, 77, 259-267. DOI: $\quad$ https://doi.org/10.1016/j.renene.2014.12.020 
Rahman, I., \& Reynolds, D. (2016). Predicting green hotel behavioral intentions using a theory of environmental commitment and sacrifice for the environment. International Journal of Hospitality Management, 52, 107-116. DOI: https://doi.org/10.1016/j.ijhm.2015.09.007

Ringle, C. M., Wende, S., \& Becker, J. M. (2015). SmartPLS 3. SmartPLS GmbH, $\quad$ Boenningstedt. Journal of Service Science and Management, 10(3). http://www.smartpls.com

Stone, G. P. (1954). City shoppers and urban identification: observations on the social psychology of city life. American Journal of Sociology, 60(1), 36-45. DOI: https://doi.org/10.1086/221483

Verma, V. K., Chandra, B., \& Kumar, S. (2019). Values and ascribed responsibility to predict consumers' attitude and concern towards green hotel visit intention. Journal of Business Research, 96, 206-216. DOI: https://doi.org/10.1016/j.jbusres.2018.11.021

Wang, L. (2020). Determinants of Consumers Purchase Attitude and Intention Toward Green Hotel Selection. Journal of China Tourism Research, 1-20.DOI: $\quad$ https://doi.org/10.1080/19388160.2020.1816241

Wang, L., Wong, P. P. W., Narayanan Alagas, E., \& Chee, W. M. (2019). Green hotel selection of Chinese consumers: a planned behavior perspective. Journal of China Tourism Research, 15(2), 192-212. DOI: https://doi.org/10.1080/19388160.2018.1553743

Welsch, H., \& Kühling, J. (2009). Determinants of pro-environmental consumption: The role of reference groups and routine behavior. Ecological economics, 69(1), 166-176. https://doi.org/10.1016/j.ecolecon.2009.08.009 